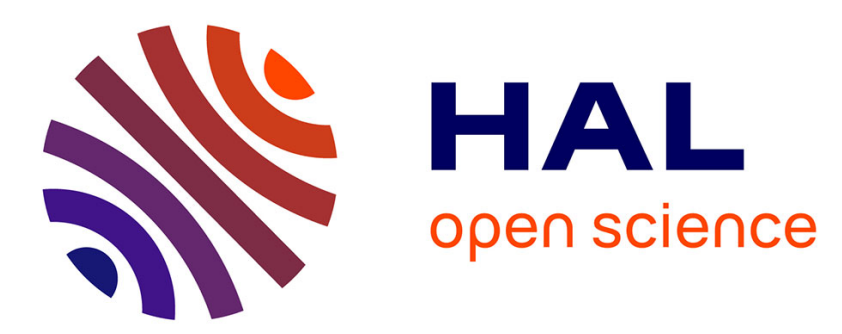

\title{
Thermal performance modelling of solar collector with heat storage
}

\author{
Guy Bertrand Tchaya, Martin Kamta, Michel Havet, César Kapseu
}

\section{To cite this version:}

Guy Bertrand Tchaya, Martin Kamta, Michel Havet, César Kapseu. Thermal performance modelling of solar collector with heat storage. International Journal of Engineering Systems Modelling and Simulation, 2017, 9 (1), pp.53-62. 10.1504/IJESMS.2017.081748 . hal-01798553

\section{HAL Id: hal-01798553 \\ https://hal.science/hal-01798553}

Submitted on 23 May 2018

HAL is a multi-disciplinary open access archive for the deposit and dissemination of scientific research documents, whether they are published or not. The documents may come from teaching and research institutions in France or abroad, or from public or private research centers.
L'archive ouverte pluridisciplinaire HAL, est destinée au dépôt et à la diffusion de documents scientifiques de niveau recherche, publiés ou non, émanant des établissements d'enseignement et de recherche français ou étrangers, des laboratoires publics ou privés. 


\title{
Thermal performance modelling of solar collector with heat storage
}

\section{Guy Bertrand Tchaya*}

Renewable Energy Department, Higher Institute of the Sahel, The University of Maroua, P.O Box 46, Cameroon Email: tchayaguy@yahoo.com Email: tchayaguy@gmail.com *Corresponding author

\section{Martin Kamta}

Electric Department, University Institut of Technologie, University of Ngaoundéré, P.O Box 455, Ngaoundéré, Cameroon Email: martin_kamta@yahoo.fr

\section{Michel Havet}

Department of Food Process Engineering, ONIRIS, UMR CNRS GEPEA, Géraudière, Street, CS 82225, 44322 NANTES Cedex 03, France

Email: michel.havet@oniris-nantes.fr

\section{César Kapseu}

ENSAI,

Department of Process Engineering, University of Ngaoundéré, P.O Box 455, Ngaoundéré, Cameroon Email: kapseu@yahoo.fr

\begin{abstract}
Solar drying is used to reduce post-harvest losses. An indirect solar dryer with oriented air is presented. It provides the ability to store energy. This work predicts the outlet temperature at the collector in the single-face and bifacial modes of collector. The heat balance applied to each element is determined taking into account the temporal term which characterises storage in the material. The simulation is done using Matlab software. Both models of the collector are validated by comparing the experimental and theoretical curves. The results show that the two curves of outlet temperatures have the same profile when the global heat transfer coefficient loss is $2.94 \mathrm{~W} \cdot \mathrm{m}^{-2} \cdot \mathrm{K}^{-1}$, the contact resistance between the absorber and the insulator is $0.025 \mathrm{~W}^{-1} . \mathrm{m} 2 . \mathrm{K}$ and the velocity is $0.2 \mathrm{~m} . \mathrm{s}^{-1}$. The contact resistance has a significant influence on the outlet air temperature but not accessible for controlling temperature compared to the velocity.
\end{abstract}

Keywords: indirect solar dryer; solar collector; heat transfer; mathematical model.

Reference to this paper should be made as follows: Tchaya, G.B., Kamta, M., Havet, M. and Kapseu, C. (2017) 'Thermal performance modelling of solar collector with heat storage', Int. J. Engineering Systems Modelling and Simulation, Vol. 9, No. 1, pp.53-62.

Biographical notes: Guy Bertrand Tchaya is a Junior Lecturer at the University of Maroua. He received his Master's degree in Electronics, Electrotechnics and Automation (EEA) in 2009. Since 2009, he has been preparing his $\mathrm{PhD}$ thesis on optimisation and modelling of indirect solar drying by the regulation of certain parameters, application to sheanuts. His main range of scientific interests is solar energy. He has four communications about solar energy and two papers. 
Martin Kamta is an Associate Professor in Electronics at the University of Ngaoundere. His main range of scientific interests is physics of semiconductor devices, electronics and photovoltaic systems. He has published three articles in electron spin resonance (ESR) of defects in III-V materials, three articles in superconducting materials, one article and six communications about photovoltaic systems. He has supervised several PhD, several Master's degree theses and several Master engineering.

Michel Havet received his Doctorate in Aerodynamics, Fluid Mechanics, Combustion and Thermal from the University of Poitiers in 1995. He is currently in charge of Food Process Engineering Department at ONIRIS, France. His research activities concern the aerodynamics and increased transfers in food processing. He has published close to 25 papers in refereed journals and has supervised several Masters and $\mathrm{PhD}$ theses.

César Kapseu is a Professor of Process Engineering at the University of Ngaoundere. He has published close to 100 papers in refereed journals and is a holder of more than ten prestigious awards. He has supervised several Masters and $\mathrm{PhD}$ theses. He has equally held several posts of responsibilities at the University of Ngaoundere.

\section{Introduction}

Sun natural drying is one of the most common traditional preservation methods used, in particular in non-industrialised countries (Lyes and Belhamri, 2006). Based on the mode of operation, the dryer is either designed as a direct, an indirect, or a mixed-mode dryer (Belessiotis and Delyannis, 2011; El-Sebaii and Shalaby, 2012). A direct-mode dryer has no preheating device to condition the drying air before entry into the drying chamber. The indirect-mode dryer has a separate device which pre-heats and lowers the relative humidity of the drying air which is directed to dry the crop in an opaque chamber. The mixed-mode dryer has both a preheater and a glazed drying chamber wall to combine the effects of the first two. The indirect dryer presents many advantages in term of products quality and possibility of controlling the parameters of the system (Figure 1) (Tchaya et al., 2014). Pirasteh et al. (2014) showed the importance of solar drying application. An important review regarding the various details such as design, construction and operational principles of practical solar dryers is reported by Ekechukwu and Norton (1999). The collector was used to heat ambient air using free solar energy. Many authors presented a design and study, based on heat transfer applied to the solar collector (Duffie and Beckmann, 2006; Tchinda, 2009). The authors obtained the differential equations which are written to describe the heat behaviour of each part of collector. The other equations are algebraic and nonlinear (Combes, 1981; Hegazy, 2000; Ong, 1995). These equations are solved in certain conditions without taking into account the material propriety of absorber in case of heat storage.

Simulation models play an important role in the development of drying systems. It helps to predict the drying parameters as temperature, velocity and relative humidity. The purpose of this work is to present mathematical modelling of solar air heaters. The validation, which is an important step in mathematical modelling development, is obtained by the comparison between experimental values and theoretical results.
Figure 1 Indirect solar dryer with oriented airflow, (a) design of indirect solar dryer (b) photograph of indirect solar dryer (see online version for colours)

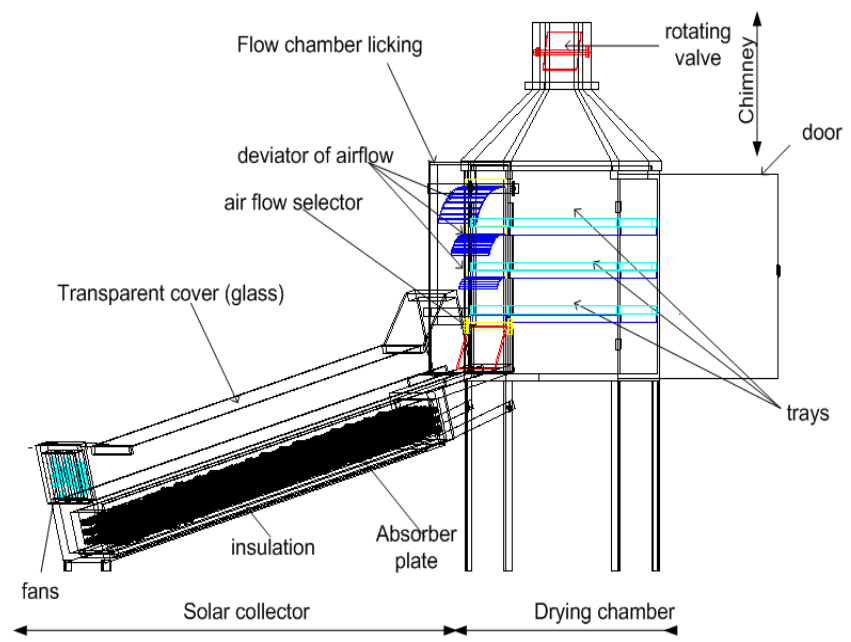

(a)

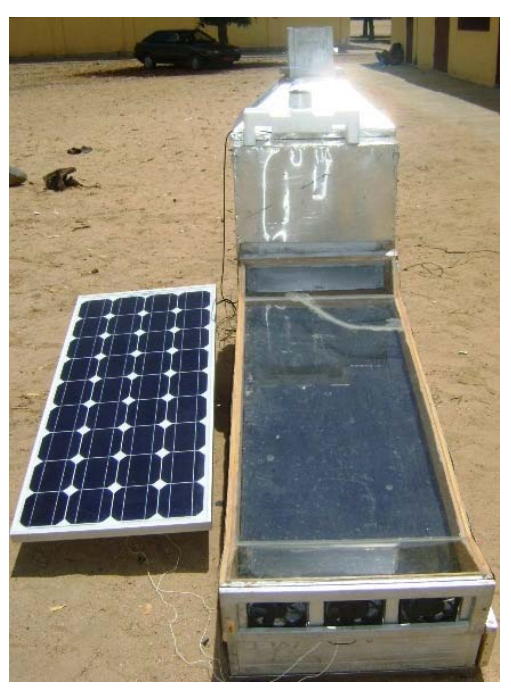

(b)

Source: Tchaya et al. (2014) 


\section{Presentation of the indirect solar dryer oriented with airflow}

An indirect solar dryer was designed and experimented in the far north region of Cameroon (longitude $10^{\circ} 35^{\prime} 27 \mathrm{~N}$ latitude $\left.14^{\circ} 18^{\prime} 57 \mathrm{E}\right)$. Indirect solar drying or convective solar drying is more efficient than the direct solar drying. This method of drying is used to avoid direct exposure to the solar radiation. The heating process is either passive or active. In this method the atmospheric air is heated in flat plate collector.

The solar collector presented in Figure 2 has three configurations with a single cover solar air heater: back-pass solar air heater without storage, parallel-pass solar air heater without storage and the back-pass solar air heater with storage.

Figure 2 Solar collector (see online version for colours)

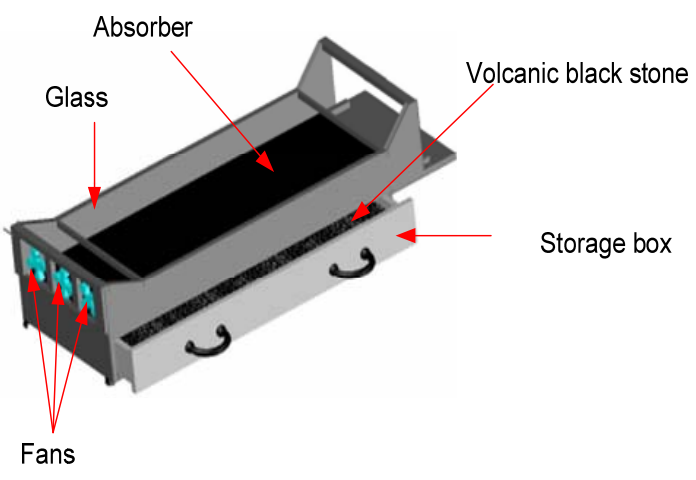

\section{Mathematical models of solar collector}

In literature, there are two main methods to model the solar collector:

- The first is a nodal method. It consists in cutting the system in fictitious slices in the direction of airflow and in writing the balanced equations on each control volume. It permits especially to predict the yield of the system and the outlet temperature of air (Belghit et al., 1997; Duffie and Beckmann, 1980).

- The second is a global method. It treats the system as a whole. It gives better explanatory approaches to the thermal behaviour of the system at any point (Combes, 1981; Hegazy, 2000; Ong, 1995; Zhai et al., 2005).

To simplify the study of the transfer energy at the solar collector, we adopted the following assumptions:

The thicknesses of the glass $(3 \mathrm{~mm})$ and the absorber (2 $\mathrm{mm}$ ) are negligible so that we cannot consider the conduction in the glass and in the absorber. In this case, the absorber is in steel or aluminum.

In the case of the storage, volcanic stones are used. The storage material is crushed and spread over the homogeneous bed in the storage box.

\subsection{Single-pass solar air heater without storage}

This design consists of a single channel with a single air flow between the cover and the absorber plate (Figure 3). The absorber is stuck in the insulation. Many authors have investigated the thermal performance of this design (Forson et al., 2003; Garg et al., 1981; Njomo, 1991; Ong, 1995; Paisarn and Kongtragool, 2003). Garg et al. (1981) developed the transient heat transfer model of a single one cover solar air heater.

Figure 3 A schematic view of a single channel solar air heater

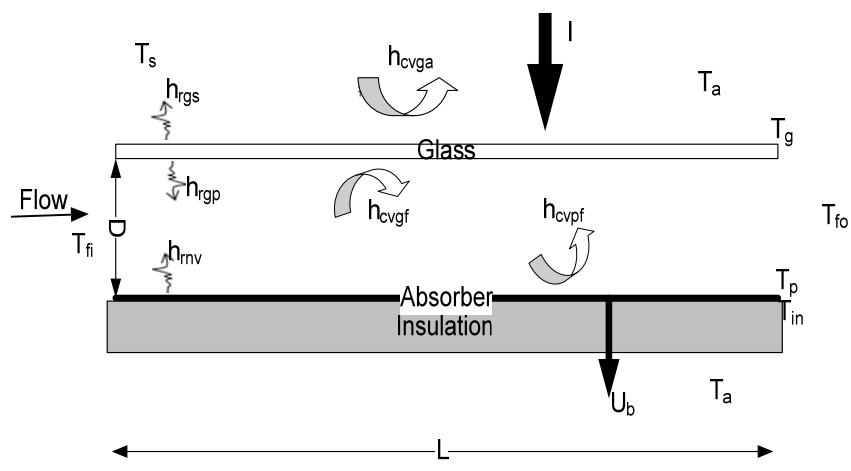

Figure 3 shows the different heat exchanges involved in this system. This model can characterise the collector without considering the effect of storage in relation to the method used for solving equations. However, the airflow, which seems to influence the heating of the air at the output of the collector is optimised by some authors.

Roger (1980) optimised the distance between the glass and the absorber as an insulator compared with the transmission by conduction. But if this distance $(e)$ is too large, a natural convection of air occurs, which leads to significant losses by convection. The optimal condition is: $\left(T_{p}-T_{g}\right) e^{3}<k$ ( $k$ depends on the fluid concerned).

Hegazy (2000) suggested that if $L$ is the length of the sensor and D the distance of the gap between glass and absorber, the optimum condition of the airflow (heat transfer fluid) is obtained if $\mathrm{D} / \mathrm{L}=2.5 \times 10^{-3}$.

With general assumptions of the heat transfer modelling, the energy balance equations of the different components of the solar air heater are written as following:

- for the cover glass

$$
\begin{aligned}
\frac{M_{g} c_{g}}{S_{g}} \frac{d T_{g}}{d t}= & P_{g}-h_{r g s}\left(T_{s}-T_{g}\right)+h_{c v g a}\left(T_{a}-T_{g}\right) \\
& +h_{r g p}\left(T_{p}-T_{g}\right)+h_{c v g f}\left(T_{f}-T_{g}\right)+P_{p g}
\end{aligned}
$$

- for the absorber plate

$$
\begin{aligned}
\frac{M_{p} c_{p}}{S_{p}} \frac{d T_{p}}{d t}= & P_{p}+h_{r p g}\left(T_{g}-T_{p}\right)+h_{c v p f}\left(T_{f}-T_{p}\right) \\
& +K\left(T_{i n}-T_{g}\right) .
\end{aligned}
$$

The inverse of $K$ is a contact resistance between absorber and insulation 
- for the insulation

$$
\frac{M_{\text {in }} c_{\text {in }}}{S_{\text {in }}} \frac{d T_{\text {in }}}{d t}=U_{b}\left(T_{a}-T_{\text {in }}\right)+K\left(T_{p}-T_{\text {in }}\right)
$$

- for air flow

$$
\frac{M_{f} C_{f}}{S_{n}} \frac{d T_{f o}}{d t}=h_{c v p f}\left(T_{p}-T_{f o}\right)+h_{c v v f}\left(T_{g}-T_{f o}\right) .
$$

Equations (1) to (4) were solved numerically using solver ODE45 of MATLAB software. The model permits to analyse the effect of the various design parameters of the heater on its performance.

\subsection{Single-pass solar air heater with storage}

We still consider the previous figure but replace the absorber with a volcanic stone lower grain size. It forms a multilayer bed thickness of $5 \mathrm{~cm}$. The storing phenomenon by the absorber is highlighted in most of the equations on the absorber by the presence of the product mass and heat capacity of the material. For the modelling approach, the differential equation which includes product, can better handle this phenomenon. Aboul-Enein et al. (2000) found an equation that characterises the behaviour of the heat transfer fluid without storage similar to that of Ong (1995). They consider that the fluid varies in space and time; but, the resolution of the equation does not consider the time:

$$
\begin{aligned}
& M_{f} C_{f} \frac{d T_{f}}{d t}+\dot{m}_{f} C_{f} \frac{d T_{f}}{d x} d x \\
& =h_{\text {cvpf }}\left(T_{p}-T_{f}\right)+h_{\text {cvg } f}\left(T_{g}-T_{f}\right)
\end{aligned}
$$

During the storage, equation (1) on the glass is similar to that obtained by Tchinda (2009) but the balanced equation in the absorber becomes like that according to Enein et al. (2000).

$$
\begin{aligned}
& P_{p}=h_{r p g}\left(T_{g}-T_{p}\right)+h_{c v p f}\left(T_{f}-T_{p}\right)+U_{s t}\left(T_{s t}-T_{p}\right) \\
& U_{s t}\left(T_{s t}-T_{p}\right)=M_{s t} c_{s t} \frac{d T_{s t}}{d t}+U_{b}\left(A_{b}+A_{s t}\right)\left(T_{s t}-T_{a}\right)
\end{aligned}
$$

The equations obtained are similar to those characteristic of the model where the absorber is stuck in the insulation. The differential equations (unsteady state) were considered to take into account the storage phenomenon.

\subsection{Parallel-pass solar air heater}

The solar air heater configuration under consideration is shown in Figure 4. It consists of one cover, double channel design with double air flows between the cover and the absorber plate and between the absorber and the bottom plates. Many papers have investigated this design (Yeh et al., 1999; Njomo, 1998; VijayaVenkataRaman et al., 2012). Jha et al. (1992) obtained the energy balanced equations in partial differential forms, which govern the behaviour of the system, by considering energy conversation on each component of the system separately.
Figure 4 Schematic view of a double channel solar air heater

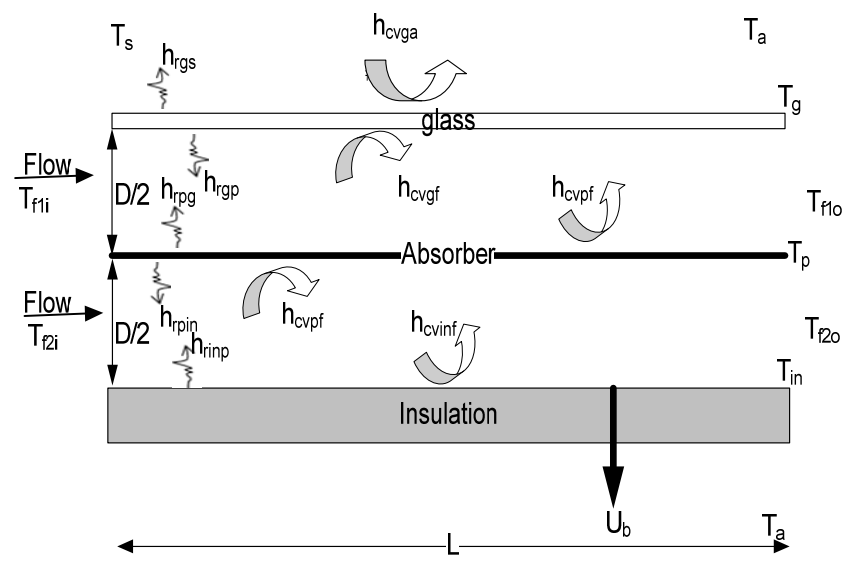

In this case, the absorber is equidistant from the glass and the insulation. This model has been explored by several authors and the equations are linear steady state (Aboul-Enein, 2000; Hegazy, 1999; Yeh et al., 1999; McAdams, 1954; Ong 1995) or linear unsteady state (differential equations) (Hegazy, 1999; Tchinda, 2009).

For the solar heater shown in Figure 4, the following equations were obtained:

- for the glass

$$
\begin{aligned}
h_{r g s}\left(T_{g}-T_{s}\right)= & P_{g}+P_{p g}+h_{c v g a}\left(T_{a}-T_{g}\right) \\
& +h_{r g p}\left(T_{p}-T_{g}\right)+h_{c v g f}\left(T_{f}-T_{g}\right)
\end{aligned}
$$

- for air flow between the cover and the absorber plate

$$
\begin{aligned}
& \dot{m} C_{f} \Delta T_{f}=h_{c v p f} l \Delta x\left(T_{p}-T_{f 1}\right)+h_{c v g f} l \Delta x\left(T_{g}-T_{f 1}\right) \\
& T_{f 1}=\left(T_{f o}+T_{f i}\right) / 2
\end{aligned}
$$

- $\quad$ for the absorber

$$
\begin{aligned}
h_{r p g}\left(T_{p}-T_{g}\right) & =P_{p}+h_{c v p f}\left(T_{f 1}-T_{p}\right)+h_{r p i n}\left(T_{i n}-T_{p}\right) \\
& +h_{c v p f}\left(T_{f 2}-T_{p}\right)
\end{aligned}
$$

- for air flow between insulation and the absorber plate

$$
\begin{aligned}
& \dot{m} C_{f} \Delta T_{f}=h_{c v p f} l \Delta x\left(T_{p}-T_{f 2}\right)+h_{c v g f} l \Delta x\left(T_{g}-T_{f 2}\right) \\
& T_{f 2}=\left(T_{f o}+T_{f i}\right) / 2
\end{aligned}
$$

- for the insulation

$$
U_{b}\left(T_{\text {in }}-T_{a}\right)=h_{\text {rinn }}\left(T_{p}-T_{\text {in }}\right)+h_{\text {cvinf }}\left(T_{f 2}-T_{\text {in }}\right) .
$$

$\Delta T_{f}=T_{f o}-T_{f i}$ is introduced in the equation (12).

$$
\begin{aligned}
2 \dot{m} C_{f}\left(T_{f 1}-T_{f i}\right)= & h_{c v p f} \operatorname{Ll}\left(T_{p}-T_{f 1}\right) \\
& +h_{c v g f} \operatorname{Ll}\left(T_{g}-T_{f 1}\right) \\
2 \dot{m} C_{f}\left(T_{f 2}-T_{f i}\right)= & h_{c v p f} \operatorname{Ll}\left(T_{p}-T_{f 2}\right) \\
& +h_{\text {cvinf }} \operatorname{Ll}\left(T_{i n}-T_{f 2}\right)
\end{aligned}
$$

By combining the previous equations, we have a system such that 


$$
\begin{aligned}
& {\left[\begin{array}{ccccc}
a 1 & a 2 & a 3 & 0 & 0 \\
b 1 & b 2 & b 3 & 0 & 0 \\
c 1 & c 2 & c 3 & c 4 & c 5 \\
0 & 0 & d 3 & d 4 & d 5 \\
0 & 0 & e 3 & e 4 & e 5
\end{array}\right]\left[\begin{array}{c}
T_{g} \\
T_{f 1} \\
T_{p} \\
T_{f 2} \\
T_{i n}
\end{array}\right]} \\
& =\left[\begin{array}{c}
h_{r g s} T_{s}+h_{c v g a} T_{a}+P_{p}+P_{p g} \\
\frac{-2 \dot{m}_{f} C_{f}}{L l} T_{f i} \\
P_{n} \\
\frac{-2 \dot{m}_{f} C_{f}}{L l} \\
-K T_{a}
\end{array}\right]
\end{aligned}
$$

The matrix method (pseudo-steady state) was applied after some hypotheses.

The matrix parameters are detailed in the following section.

\section{The convective heat transfer coefficient}

Glass-ambient air and insulation-ambient air.

McAdams obtained the experimental result

$$
h_{\text {cvga }}=5.67+3.86 \mathrm{~V}=h_{\text {cvina }}
$$

With $0<V<5 \mathrm{~m} / \mathrm{s}$

Watmuff et al. (1977) used the following empirical equation

$$
h_{\text {cvga }}=2.8+3.3 \mathrm{~V}=h_{\text {cvina }}
$$

$V$ is the wind velocity $(\mathrm{m} / \mathrm{s})$.

$D_{h}$ is the equivalent diameter (hydraulic diameter)

$$
h_{c v p f}=\frac{N_{u} \lambda_{f}}{D_{h}}
$$

The calculations of convective heat coefficients have been performed considering the predominant natural convection because we found that $\frac{G_{r}}{R_{e}^{2}}<<1$. Ong (1995) and Aboul-Enein et al. (2000) found the same results in their configuration when they presented the model of a collector.

\subsection{The conduction heat transfer coefficient}

On glass

$$
h_{c d g}=\frac{\lambda_{g}}{e_{g}}
$$

In this modelling, we will neglect the thickness of the glass.

The absorber

$$
h_{c d p}=\frac{\lambda_{p}}{e_{p}}
$$

This thickness is negligible.

On the insulator

$$
h_{c d i n}=\frac{\lambda_{i n}}{e_{i n}}
$$

\subsection{The radiative heat transfer coefficient}

The glass and sky

$$
h_{r s g}=\sigma \varepsilon_{g}\left(T_{s}+T_{g}\right)\left(T_{s}^{2}+T_{g}^{2}\right)
$$

$T_{s}$ is the equivalent temperature of the sky in Kelvin. It is inaccessible to the measurement.

Some authors consider the temperature $T_{s}$ to be equal to the ambient temperature $T_{a}$ minus 6 or 7 , or sometimes 12 .

$$
\begin{aligned}
& T_{s}=T_{a}-(6,7 \text { or } 12) \text { or else } \\
& T_{s}=0.0552 T_{a}^{1.5}
\end{aligned}
$$

The glass and absorber

$$
h_{r p g}=\sigma \frac{\left(T_{p}+T_{g}\right)\left(T_{p}^{2}+T_{g}^{2}\right)}{\frac{1-\varepsilon_{p}}{\varepsilon_{n}}+\frac{1-\varepsilon_{g}}{\varepsilon_{g}}+1}
$$

The insulator and absorber

$$
h_{r p i n}=\sigma \frac{\left(T_{p}+T_{i n}\right)\left(T_{p}^{2}+T_{i n}^{2}\right)}{\frac{1-\varepsilon_{p}}{\varepsilon_{p}}+\frac{1-\varepsilon_{i n}}{\varepsilon_{i n}}+1}
$$

The insulator and ground

$$
\begin{aligned}
& h_{\text {ringnd }}=\sigma \varepsilon_{i}\left(T_{\text {in }}+T_{\text {gnd }}\right)\left(T_{\text {in }}^{2}+T_{\text {gnd }}^{2}\right), \\
& T_{\text {gnd }}=T_{a}
\end{aligned}
$$

\section{Correlations of Nusselt number}

Experiments in several laboratories have shown that to model driers for food products, we need some empirical correlations. Ong (1995) presented some models which are adapted by natural or forced convection.

\subsection{Nusselt number in forced convection}

In the laminar region $\left(R_{e}<2,300\right)$, the empirical correlation that gives the Nusselt number for a fluid flowing between two parallel surfaces with one side behaving as an insulation and whose flow heat is constant is by Heaton et al. (1964).

$$
N_{u}=N_{u \infty}+\frac{a\left[R_{e} \operatorname{Pr}\left(\frac{D_{h}}{L}\right)\right]^{m}}{1+b\left[R_{e} \operatorname{Pr}\left(\frac{D_{h}}{L}\right)\right]^{n}}
$$

where $a=0.00190 ; b=0.00563 ; m=1.71 ; n=1.17$ and $N_{u \infty}=5.4$ for $\operatorname{Pr}=0.7$.

In the transition region $\left(2,300<R_{e}<6,000\right)$, Hausen (1943) gave the empirical correlation for the Nusselt 
number average between the beginning of the hot section and the $\mathrm{L}$ position of the heat transfer fluid in the tube

$$
N_{u}=0.116\left(R_{e}^{\frac{2}{3}}-125\right) P_{r}^{\frac{1}{3}}\left[1+\left(\frac{D_{h}}{L}\right)^{\frac{2}{3}}\right]\left(\frac{\mu}{\mu_{w}}\right)^{0.14}
$$

To the region where the fluid is turbulent $R_{e}>6,000$, the Nusselt number between two parallel plates, with a $D_{h}$ diameter equal to three times the separation of the two plates is given by Nusselt (1931)

$$
N_{u}=0.036 R_{e}^{0.8} P_{r}^{\frac{1}{3}}\left(\frac{D_{h}}{L}\right)^{0.055}
$$

\subsection{Nusselt number in natural convection}

In the case where the fluid flows over an inclined plate of a $\theta$ angle, calculating the Nusselt number is expressed following Fujii and Imura (1972).

To an inclined plate:

If $\theta<80^{\circ}, 10^{5} G_{r L} P_{r}<10^{11}$ and the heating surface facing down

$$
N_{u}=0.56\left(G_{r L} P_{r} \cos \theta\right)^{1.4}
$$

If $\begin{gathered}r L>G_{r c} \\ 88<\theta<90^{\circ}, G_{r L} P_{r}>10^{11}, G\end{gathered}$ and heating side of the plate is inclined upwardly, it will then

$$
\begin{aligned}
N_{u}= & 0.145\left[\left(G_{r L} P_{r}\right)^{\frac{1}{3}}-\left(G_{r c} P_{r}\right)^{\frac{1}{3}}\right] \\
& +0.56\left(G_{r c} P_{r} \cos \theta\right)^{1 / 4}
\end{aligned}
$$

$G_{r c}$ is the number of Grashof which depends on the angle of inclination (to the angular value of $-75^{\circ}$ it is 106 and, to an angle of $-60^{\circ}$, it is 108 ).

For an inclined plate and therefore $0^{\circ}<\Phi<60^{\circ}$ Holland et al. (1976) proposed this correlation for $0<R_{a}<10^{5}$.

$$
\begin{aligned}
N_{u}=1 & +1.44\left[1-\frac{1708}{R_{a} \cos \theta}\right]^{*}\left[1-\frac{1708(\sin 1.8 \theta)^{1,6}}{R_{a} \cos \theta}\right] \\
& +\left[\left(\frac{R_{a} \cos \theta}{5830}\right)^{\frac{1}{3}}-1\right]^{*}
\end{aligned}
$$

The notation [] $*$ means that if the quantity is negative, it is assigned the number zero.

\section{Yields}

The instant yields of solar collector are defined relative to the incident solar flux as follows:

$$
\text { Global yield } \gamma=\frac{\dot{m} C_{f}\left(T_{f o}-T_{f i}\right)}{\int I S_{p} d t}
$$

Internal yield $\gamma=\frac{\dot{m} C_{f}\left(T_{f o}-T_{f i}\right)}{\alpha \tau I}$

\section{Results and discussion}

\subsection{Simulation of heat exchange in the single-sided of collector plate made with steel absorber (Figure 5)}

The theoretical temperature of the absorber $\left(\mathrm{T}_{\mathrm{pmod}}\right)$ is greater than that of the glass $\left(\mathrm{T}_{\mathrm{gmod}}\right)$ because it receives more energy.

Figure 5 Profile of temperatures with steel absorber (see online version for colours)

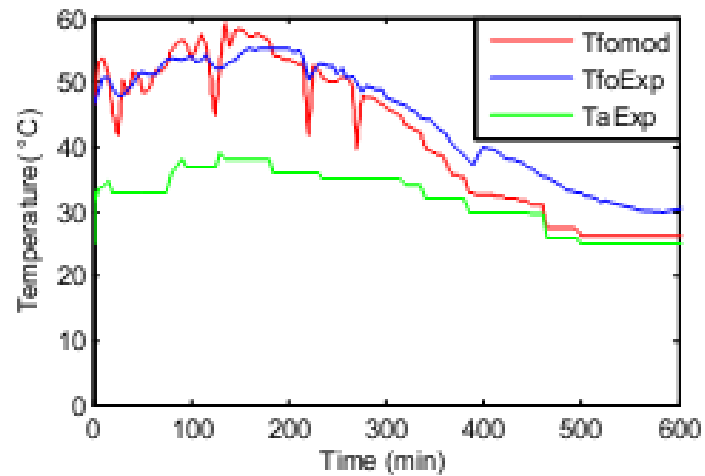

The experimental temperature of the absorber $\left(T_{\mathrm{pExp}}\right)$ is low compared to $\mathrm{T}_{\text {pmod }}$ because it is measured at the surface of the absorber where it is influenced by the heat transfer fluid. $\mathrm{T}_{\mathrm{pExp}}$ and $\mathrm{T}_{\text {pmod }}$ have the same profile. Indeed the same irradiance is applied to the input of the two cases.

The experimental temperature of fluid outlet $\left(\mathrm{T}_{\text {foExp }}\right)$ has the same profile as $T_{\text {fomod. }}$. There is an energy storage in the afternoon which maintains high $\mathrm{T}_{\text {foExp }}$ while $\mathrm{T}_{\text {fomod }}$ has already reached its minimum. This difference is a defect in the material used compared with theoretical data.

The air temperature $\mathrm{T}_{\text {fomod }}$ reached $61^{\circ} \mathrm{C}$ in the case of steel for an average irradiance of $591.41 \mathrm{~W} / \mathrm{m}^{2}$.

\subsection{Simulation of heat exchange in the single-sided of collector plate made with aluminum absorber}

In Figure 6, we have the same observations as in the case of steel absorber but the peaks observed on the curves shows that the aluminum absorber is more sensitive compared to the steel. The air temperature $\mathrm{T}_{\text {fomod }}$ reaches $67^{\circ} \mathrm{C}$ in the case of aluminum for an average irradiance of $654.43 \mathrm{~W} / \mathrm{m}^{2}$. 
Figure 6 Profile of temperatures with aluminum absorber (see online version for colours)

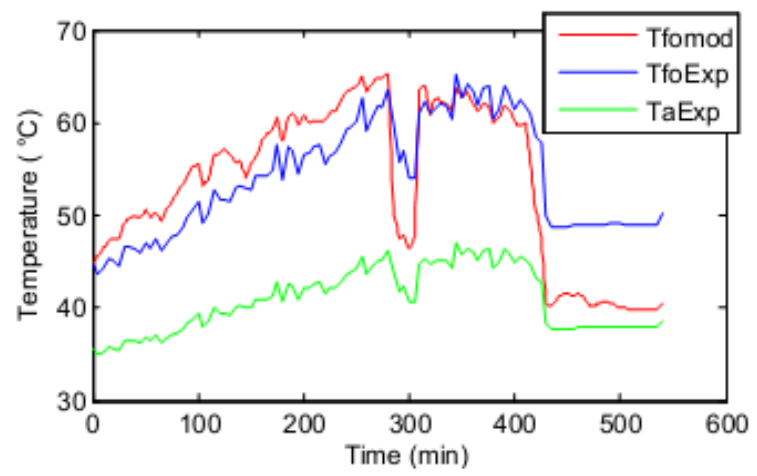

\subsection{Storage through the volcanic stone}

The model takes into account the storage phenomenon. It presents the product of mass and heat capacity of the material. This term is in the differential equations. Solving the system of equations was made by MATLAB using the solver ODE45.

In Figure 7, $\mathrm{T}_{\text {foExp }}$ and $\mathrm{T}_{\text {fomod }}$ have the same profile and can also reach respectively values of $60^{\circ} \mathrm{C}$ and $63^{\circ} \mathrm{C}$.

The difference between $\mathrm{T}_{\text {fomod }}$ and $\mathrm{T}_{\text {foExp }}$ at the beginning is due to the failure to take into account the heterogeneity of volcanic stone bed in its space

\subsection{Influence of the loss and the contact resistance coefficient on the temperature}

The temperature of the absorber is assumed to be the temperature of inner surface of the insulator. The table below is showing that if the system has lost energy, then the temperature of the absorber $\left(\mathrm{T}_{\text {pmod }}\right)$ decreased and also reduced the output of the collector temperature $\left(\mathrm{T}_{\text {fomod }}\right)$. It is noticeable that for poor insulation, one should avoid contact with the absorber in order to increase the performance of collector.
Figure 7 Profile of temperatures with volcanic stone absorber (see online version for colours)

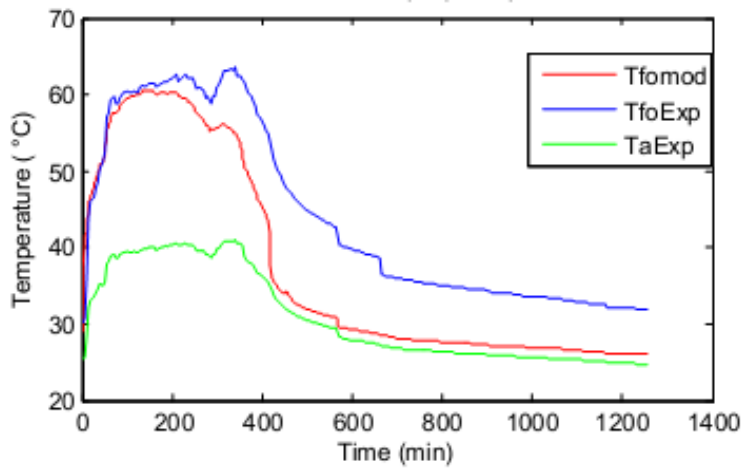

\subsection{Simulation of heat transfer in the two-sided of the collector}

\subsubsection{Steel absorber}

The theoretical temperature of the absorber $\left(\mathrm{T}_{\mathrm{pmod}}\right)$ is greater than that of the glass $\left(\mathrm{T}_{\mathrm{gmod}}\right)$ because it receives more energy (Figure 8).

The experimental temperature of the absorber $\left(\mathrm{T}_{\mathrm{pExp}}\right)$ is low compared to $\mathrm{T}_{\text {pmod. }}$. It is measured on the surface of the absorber, where it is influenced by the heat transfer fluid. $\mathrm{T}_{\mathrm{pExp}}$ and $\mathrm{T}_{\text {pmod }}$ have the same profile, as it is the same irradiance that is applied to the input of the two cases.

Figure 8 Profile of temperatures with steel absorber (see online version for colours)

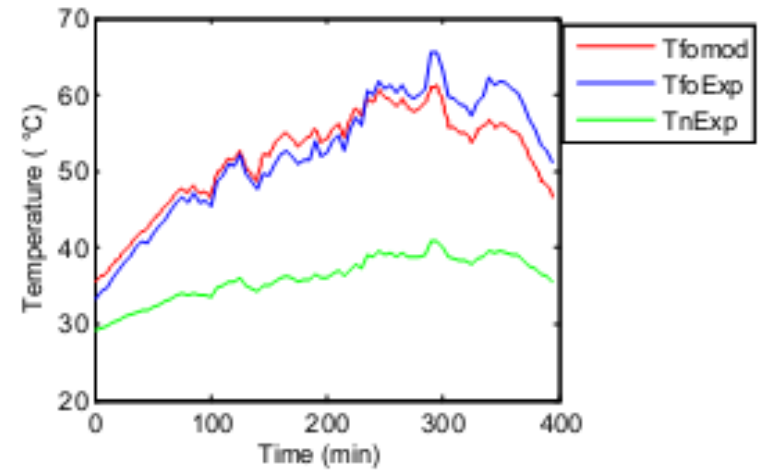

Table 1 Influence of the loss $\left(\mathrm{U}_{\mathrm{b}}\right)$ and the contact resistance $1 / \mathrm{K}$ on $\mathrm{T}_{\mathrm{fs}}$ and $\mathrm{T}_{\mathrm{n}}$

\begin{tabular}{|c|c|c|c|c|c|}
\hline \multirow{3}{*}{ Designation } & \multicolumn{3}{|c|}{ Variation of contact resistance coef } & \multicolumn{2}{|c|}{ Variation of loss coef } \\
\hline & \multicolumn{3}{|c|}{$U_{b}>>2.94$} & \multicolumn{2}{|c|}{$K=40$} \\
\hline & $10<K<40$ & $K>>40$ & $K<10$ & $U_{b}=2.94$ & $U_{b}<<2.94$ \\
\hline Absorber temperature $\left({ }^{\circ} \mathrm{C}\right)$ & $150-200$ & $120-150$ & $>250$ & $120-150$ & $150-170$ \\
\hline Outlet air $\max \left({ }^{\circ} \mathrm{C}\right)$ & 50 & $<50$ & 70 & 50 & 60 \\
\hline Conclusion & \multicolumn{3}{|c|}{ In case of poor insulation, use $K$ to adjust } & \multicolumn{2}{|c|}{$\begin{array}{l}\text { In absence of energy loss, temperature } \\
\text { increases but has a limit }\end{array}$} \\
\hline
\end{tabular}


The distribution of the fluid inlet of the air flow on both sides is equal, the air temperature of the upper corridor $\mathrm{T}_{\mathrm{fs} \text { theo }}$ absorber is higher than the air temperature of the lower corridor $\mathrm{T}_{\text {fo2mod }}$ absorber (Figure 9). It is considered that the $\mathrm{T}_{\text {fomod }}$ outlet temperature of the collector is the average of these two temperatures (Figure 9).

Figure 9 Profile of collector temperature outlet (see online version for colours)

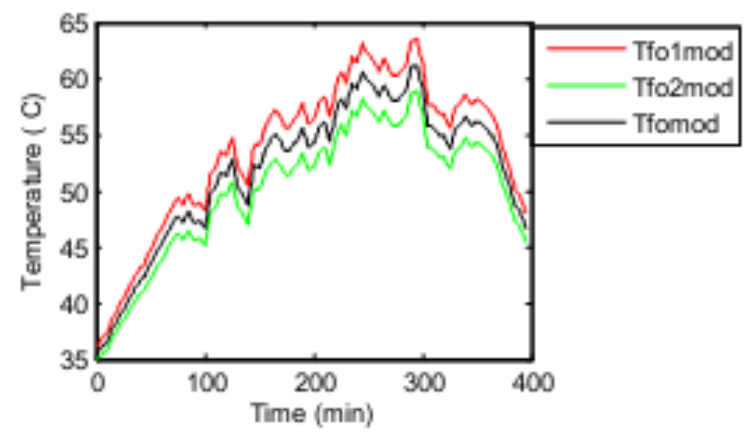

The experimental temperature fluid outlet $\mathrm{T}_{\text {foExp }}$ has the same profile as the theoretical $\mathrm{T}_{\text {fomod }}$ outlet temperature. The temperature $\mathrm{T}_{\text {foExp }}$ reached $65^{\circ} \mathrm{C}$, while the theoretical is about of $60^{\circ} \mathrm{C}$ under the same input conditions change.

In general, the convection transfer coefficients of the collector system are not high in view of all the correlations that we found in the literature. Indeed Ong (1995) presented a curve of the evolution of the Nusselt number as a function of $\mathrm{L} / \mathrm{D}$ and knowing $R_{e}$. In this case for $R_{e} \leq 1,000$ we have $5 \leq N_{u} \leq 25$.

\subsubsection{Aluminum absorber}

We have the same observations as in the previous case; but, the type of absorber material is felt by the sensitivity of aluminum compared to steel. Indeed, we can observe a lot of ripple on $\mathrm{T}_{\text {pmod }}$ and $\mathrm{T}_{\text {fomod }}$ (Figure 10).

\subsection{Influence of air velocity on the model of the collector}

Temperature $\mathrm{T}_{\text {pmod }}$ absorber is high compared with the air temperature $\mathrm{T}_{\text {fomod. }}$. The average gap is of the order of $100^{\circ} \mathrm{C}$. We can say that the exchange with the air is not optimal. Sensitive parameters that can enable this optimisation are eg the fluid velocity, convective exchanges, loss ratios, the contact resistance (absorber and insulation) and the hydraulic diameter.

Table 2 shows a theoretical comparative study of parameters of influence for Model 1 and 2 of the thermal sensor. It can be concluded that the velocity parameter influences significantly $\mathrm{T}_{\text {fomod. }}$. It can be noticed that this parameter is accessible.

This table shows that, for a velocity of $0.002 \mathrm{~m} / \mathrm{s}$, the air temperature can reach $230^{\circ} \mathrm{C}$ in the case of aluminum and $280^{\circ} \mathrm{C}$ in the case of steel.

It shows that, in case of utilisation of the same material, the model with double channels is heating than the model with single channel.

\subsection{The performance of collector}

We used the equations to estimate the internal and overall performance of the collector in the case of optimal parameters $\left(\mathrm{v}=0.2 \mathrm{~m} / \mathrm{s}, \mathrm{Ub}=2.94 \mathrm{~W} / \mathrm{m}^{2} \mathrm{~K}\right)$. The theoretical internal efficiency is around of 0.55 .

The theoretical internal efficiency ( $\mathrm{Int}_{\mathrm{mod}}$ ) is higher than the experimental one $\left(\mathrm{Int}_{\mathrm{Exp}}\right)$ and the theoretical global efficiency $\left(\mathrm{Glob}_{\mathrm{mod}}\right)$ is also higher than the experimental one $\left(\mathrm{Glob}_{\mathrm{Exp}}\right)$ because the characteristics of material used to simulate are ideal.

The performance range of flat plate solar collectors indicated by Yeh et al. (2002) to a mass flow $38.52 \mathrm{~kg} / \mathrm{h}$, is 0.6 to 0.65 (Figure 11). According to Maiiti et al. (2011), the yield increases with time in a dryer to a maximum of $60 \%$ in a heater plate.

Figure 10 Profile of temperatures with aluminum absorber (see online version for colours)

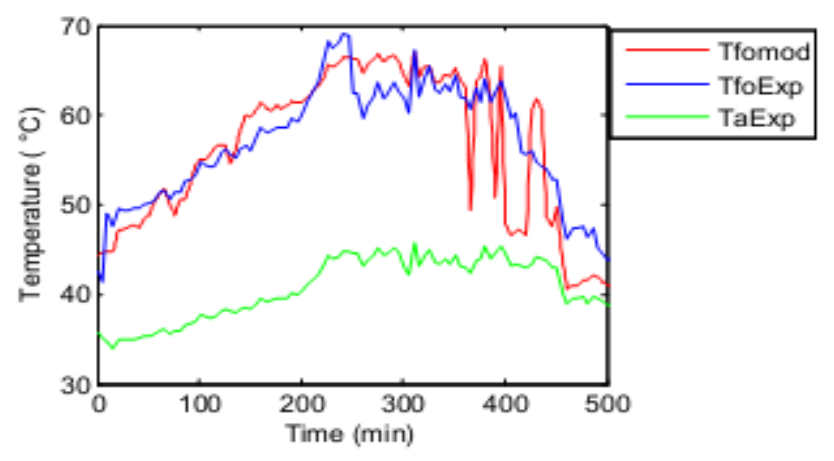

Table 2 Influence of parameters for both models of collector

\begin{tabular}{|c|c|c|c|c|c|c|}
\hline \multirow{3}{*}{ Parameters } & & \multicolumn{5}{|c|}{ Outlet theoretical temperature $\left({ }^{\circ} \mathrm{C}\right)$} \\
\hline & & \multicolumn{3}{|c|}{ Model with single sided of collector } & \multicolumn{2}{|c|}{ Model with double sides of collector } \\
\hline & & Steel & Aluminum & Storage & Steel & Aluminum \\
\hline $\mathrm{K}=40$ & & 58 & 65 & Not exist & & \\
\hline $\mathrm{Ub}=2.94$ & & 58 & 65 & 63 & 62 & 68 \\
\hline \multirow[t]{3}{*}{ Velocity $(\mathrm{m} / \mathrm{s})$} & 1 & 47 & / & / & / & 46 \\
\hline & 0.2 & 65 & / & / & / & 68 \\
\hline & 0.002 & 280 & / & / & / & 230 \\
\hline
\end{tabular}


Figure 11 Energy efficiency of the collector (see online version for colours)

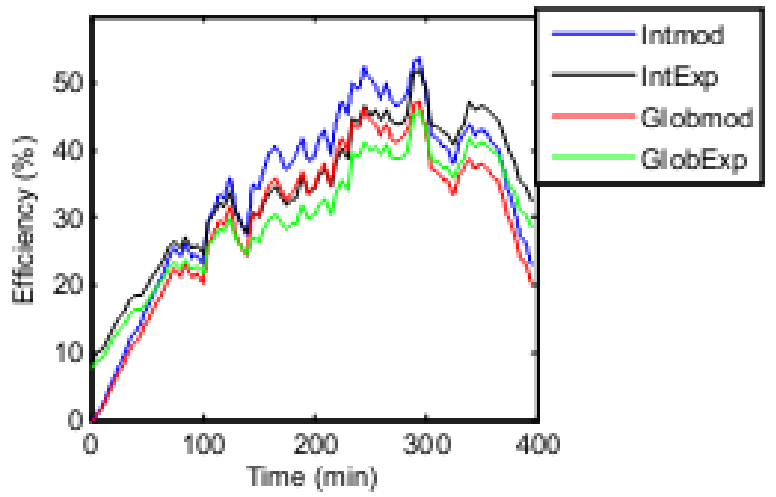

\section{Conclusions}

Many mathematical approaches have been developed for simulating the performance of solar air heaters. In this work, the mathematical modelling is given by taking in account the thermal resistance between absorber and insulation. The model has been validated against several experimental results and used to perform a sensitivity analysis.

Results indicate that air velocity appears to be the more relevant parameter to control the outlet temperature.

The quality of thermal contact resistance between the absorber and the insulation should be taken into account. In this case, a value of about $0.025 \mathrm{~W}^{-1} \cdot \mathrm{m}^{2} . \mathrm{K}$ was required to guarantee a good performance of collector. This parameter can also help in the control of outlet temperature but there is a problem of accessibility. Using the model, a control algorithm will be designed in order to deliver the air in the temperature range acceptable for the quality of the products in the dryer.

\section{Acknowledgements}

The authors would like to thank the International Foundation of Sciences (IFS) for its financial assistance (Grant No. E/5173-1).

\section{References}

Aboul-Enein, S., El-Sebaii, A.A., Ramadan, M.R.I. and ElGohary, H.G. (2000) 'Parametric study of a solar air heater with and without thermal storage for solar drying applications', Renewable Energy, Vol. 21, Nos. 3-4, pp.505-522.

Belessiotis, V. and Delyannis, E. (2011) 'Solar drying', Solar Energy, Vol. 85, No. 8, pp.1665-1691.

Belghit, A., Belahmidi, M., Bennis, A., Boutaleb, B.C. and Benet, S. (1997) 'Etude numérique d'un séchoir solaire fonctionnant en convection forcée', Rev. Gén. Therm., Vol. 36, No. 11, pp.837-850.

Combes, C. (1981) Modélisation informatique d'une synthèse de séchage solaire pour fruits et legumes, Thèse de docteur-ingénieur, Université de Perpignan.
Daguenet, M. (1985) Les séchoirs solaires: théorie et pratique, Publication de l'UNESCO, Paris.

Duffie, J.A. and Beckman, W.A. (2006) Solar Engineering of Thermal Processes, 3rd ed., John Wiley and Sons, Inc., New Jersey.

Duffie, J.A. and Beckmann, W.A. (1980) Solar Engineering of Thermal Processes, Wiley, New York.

Ekechukwu, O.V. and Norton, B. (1999) 'Review of solar-energy drying systems III: low temperature air-heating solar collectors for crop drying applications', Energy Conversion \& Management, Vol. 40, No. 6, pp.657-667.

El-Sebaii, A.A. and Shalaby, S.M. (2012) 'Solar drying of agricultural products: a review', Renewable and Sustainable Energy Reviews, Vol. 16, No. 1, pp.37-43.

Forson, F.K., Nazha, M.A.A. and Rajakaruna, H. (2003) 'Experimental and simulation studies on a single pass, double duct solar air heater', Energy Conversion and Management, Vol. 44, No. 8, pp.1209-1227.

Garg, H.P., Chandra, R. and Rani, U. (1981) 'Transient analysis of solar air heaters using finite differences technique', Energy Research, Vol. 5, No. 3, pp.243-252.

Hausen, H. (1943) Darstellung des warmenberganges in rohren durch verallgemeinerte potenzbeiziehungen, VDIZ, Vol. 4, pp.91-98.

Heaton, H.S., Reynolds, N.C. and Kays, W.M. (1964) 'Heat transfer in annular passages, simultaneous development of velocity and temperature fields in laminar flow', Int. J. Heat and Mass Transfer, Vol. 7, No. 7, p.763.

Hegazy, A.A. (1999) 'Optimum channel geometry for solar air heaters of conventional design and constant flow operation', Energy Conversion and Management, Vol. 40, No. 7, pp.757-774.

Hegazy, A.A. (2000) 'Performance of the flat solar air heaters with optimum channel geometry for constant/variable flow operation', Energy Conversion and Management, Vol. 41, No. 4, pp.401-474.

Holland, K.G.T., Unny, T.E., Raithby, G.D. and Konicek, L. (1976) 'Free convection heat transfer across inclined air layers', Trans. ASME, J. Heat Transfer, Vol. 98, No. 2, pp.189-193.

Lyes, B. and Belhamri, A. (2006) 'Numerical simulation of drying under variable external conditions: application to solar drying of seedless grapes', Journal of Food Engineering, Vol. 76, No. 2, pp.179-187.

Maiiti, S., Patel, P., Vyas, K., Eswaran, K. and Ghosh, P.K. (2011) 'Performance evaluation of a small scale indirect solar dryer with static reflectors during non-summer months in the Saurashtra Region of Western India', Solar Energy, Vol. 85, No. 11, pp.2686-2696.

McAdams, W.H. (1954) Heat Transmission, McGraw-Hill, New York.

Njomo, D. (1991) 'Modelling the heat exchanges in a solar air heater with a cover partially transparent to infrared radiation', Energy Conversion and Management, Vol. 31, No. 5, pp.495-503.

Njomo, D. (1998) 'Etude théorique du comportement thermique d'un capteur solaire plan a air a couverture combine plastique vitre', Revue Générale de Thermique, Vol. 37, No. 11, pp.973-980.

Nusselt, W. (1931) Der warmeaustatsch zwischen wand und wasser im rohr, Forsch Geb, Ingenieurwes, Berlin, Vol. 2, No. 9, p.309. 
Ong, K.S. (1995) 'Thermal performance of solar air heaters: mathematical model and solution procedure', Solar Energy, Vol. 55, No. 2, pp.93-109.

Paisarn, N. and Kongtragool, B. (2003) 'Theoretical study on heat transfer characteristics and performance of the flat-plate solar air heaters', International Communications in Heat and Mass Transfer, Vol. 30, No. 8, pp.1125-1136.

Pirasteh, G., Saidur, R., Rahman, S.M.A. and Rahim, N.A. (2014) 'A review on development of solar drying applications', Renewable and Sustainable Energy Reviews, Vol. 31, pp.13-14.

Roger, B. (1980) Le rayonnement solaire conversion thermique et applications, 2e edition, Lyon -1 Univ., 69, France.

Tchaya, G.B., Kamta, M. and Kapseu, C. (2014) 'Improvement of an indirect solar dryer with forced convection by variation of airflow mode', International Journal of Emerging Technology and Advanced Engineering, Vol. 4, No. 1, pp.518-522.

Tchinda, R. (2009) 'A review of the mathematical models for predicting solar air heaters systems', Renewable and Sustainable Energy Reviews, Vol. 13, No. 8, pp.1734-1759.

VijayaVenkataRaman, S., Iniyan, S. and Goic, R. (2012) 'A review of solar drying technologies', Renewable and Sustainable Energy Reviews, Vol. 16, No. 5, pp.2652-2670.

Watmuff, J.H., Charters, W.W.S. and Proctor, D. (1977) 'Solar and wind induced external coefficients for solar collectors', COMPLES, No. 2, p.56.

Yeh, H-M., Ho, C-D. and Hou, J-Z. (1999) 'The improvement of collector efficiency in solar air heaters by simultaneously air flow over and under the absorbing plate', Energy, Vol. 24, No. 10 , pp.857-871.

Yeh, H-M., Ho, C-D. and Hou, J-Z. (2002) 'Collector efficiency of double-flow solar air heaters with fin attached', Energy, Vol. 27, No. 8, pp.715-727.

Zhai, X.Q., Dai, Y.J. and Wang, R.Z. (2005) 'Comparison of heating and natural ventilation in a solar house induced by two roof solar collectors', Applied Thermal Engineering, Vol. 25, Nos. 5-6, pp.741-775.

\section{Nomenclature}

\begin{tabular}{|c|c|c|}
\hline$\mu$ & Dynamic viscosity of the air & $(\mathrm{kg} / \mathrm{ms})$ \\
\hline$x, y$ & space coordinate & (m) \\
\hline$C$ & Specific heat & $(\mathrm{J} / \mathrm{kg}-\mathrm{K})$ \\
\hline$\alpha$ & Absortance of the cover & \\
\hline$\tau$ & Transmitivity & \\
\hline$\rho$ & Density of solid & $\left(\mathrm{kg} / \mathrm{m}^{3}\right)$ \\
\hline$\varepsilon$ & Emissivity & \\
\hline$\sigma$ & Stefan-Boltzmann constant & $\left(\mathrm{W} . / \mathrm{m}^{2} \cdot{ }^{\circ} \mathrm{K}^{4}\right)$ \\
\hline$\lambda$ & Thermal conductivity & $(\mathrm{W} / \mathrm{m} \mathrm{K})$ \\
\hline$D h$ & hydraulic diameter & $(\mathrm{m})$ \\
\hline$L$ & Length of air heater & (m) \\
\hline$h$ & Convective heat transfer coefficient & $\left(\mathrm{W} / \mathrm{m}^{2} \mathrm{~K}\right)$ \\
\hline$K$ & Contact heat transfer coefficient & $\left(\mathrm{W} / \mathrm{m}^{2} \mathrm{~K}\right)$ \\
\hline$M$ & Mass & $(\mathrm{kg})$ \\
\hline$I$ & Irradiance & $\mathrm{W} / \mathrm{m}^{2}$ \\
\hline$T$ & Temperature & $\left({ }^{\circ} \mathrm{K}\right)$ \\
\hline$U$ & Global loss coefficient & $\left(\mathrm{W} / \mathrm{m}^{2} \mathrm{~K}\right)$ \\
\hline$v$ & Wind velocity & $(\mathrm{m} / \mathrm{s})$ \\
\hline$S$ & Area & $\left(\mathrm{m}^{2}\right)$ \\
\hline$\dot{m}$ & Mass flow rate & $(\mathrm{kg} / \mathrm{s})$ \\
\hline$G r$ & Grashof number & \\
\hline$N u$ & Nusselt number & \\
\hline $\operatorname{Pr}$ & Prandtl number & \\
\hline$R_{e}$ & Reynolds number & \\
\hline$\eta$ & Efficiency & \\
\hline$e$ & Thickness & (m) \\
\hline \multicolumn{3}{|c|}{ Subscripts } \\
\hline$a$ & Ambient (air) & \\
\hline$f$ & Fluid (air) & \\
\hline$g$ & Glass & \\
\hline$p$ & Absorber plate & \\
\hline$r$ & Radiative & \\
\hline$c d$ & Conductive & \\
\hline$c v$ & Convective & \\
\hline$i$ & Inlet & \\
\hline in & Insulation & \\
\hline$o$ & Outlet & \\
\hline$b$ & Bottom & \\
\hline$t$ & Total & \\
\hline$s t$ & Storage & \\
\hline $\operatorname{Exp}$ & Experiment & \\
\hline Mod & Model & \\
\hline
\end{tabular}

